\title{
Inhibition of Ekortikus Island Expansion in Banyuasin Estuary, South Sumatra Modelling by Using Finite Volume Method with Unstructured Mesh
}

\author{
Zulbahrum Caniago ${ }^{1}$, Ibrahim. Eddy ${ }^{1}$, Ridho. $\mathrm{M} \mathrm{R}^{1}$, Ngudiantoro ${ }^{1}$ \& Bernas. Siti $\mathrm{M}^{1}$ \\ ${ }^{1}$ Post Graduate Program of Environmental Science, Sriwijaya University, South Sumatra, Indonesia \\ Correspondence: Zulbahrum Caniago, Post Graduate Program of Environmental Science, Sriwijaya University, \\ Padang Selasa strait No, 524 Bukit Besar Palembang, South Sumatra, Indonesia. Tel: 62-812-7100-938. \\ E-mail:czulbahrum@gmail.com
}

Received: March 30, 2015 Accepted: April 14, 2015 Online Published: May 28, 2015

doi:10.5539/jsd.v8n3p294 URL: http://dx.doi.org/10.5539/jsd.v8n3p294

\begin{abstract}
Ekortikus Island was formed through continuous sedimentation in Banyuasin Estuary (BAE) in Banyuasin District, South Sumatra. Based on satellite data, Ekortikus Islands area is expanding dramatically, 22 times greater in 21-year period. This expansion narrowed the estuary and disturbing estuary function, especially related to water run off from water cathment area. Ekortikus expansion was caused by high sedimentation and flow distribution mode which were formed by the fusion of two river flows assembled in the estuary, confounded by tidal flow dynamic with amplitude of $0.6-3.9 \mathrm{~m}$. An experiment was conducted to simulate development of Ekortikus Island with or without placement of a potential barrier. The simulation used Finite Volume Method (FVM) with triangle unstructured mesh. Simulation with normal conditions or without treatment, in which the flow is Banyuasin greater than the flow Lalan turn out Ekortikus island increases toward the Southwest and due to tidal flow, Ekortikus Island increases towards the Northwest. Simulation could also manipulate the future form of the Island when a potential barrier was placed to direct flows of both rivers. Treatment simulation, by changing the flow Banyuasin becoming greater than Lalan flow, altered the location of the deposition of sediment to another place and Ekortikus Island area expansion was reduced.
\end{abstract}

Keywords: simulation, sedimentation, Finite Volume Method, potential barrier, Tanjung Api-Api, Ekortikus

\section{Introduction}

Tanjung Api-Api Region, Banyuasin District, South Sumatra Province is economically strategic that has been appointed to as Special Economy Zone (SEZ - Kawasan Ekonomi Khusus) under Government Decree number 51 year 2014. To support SEZ, both central and province governments have invested fund to build infrastructures, such as a"Tanjung Api-Api" harbor in Banyuasin Estuary (PP, 2014).

Banyuasin Estuary (BAE) is located at coordinate of 104.36' - 104. 48'West and 2.24'-2.48' Sout(h. BAE is an assemblage of two big rivers, named Banyuasin and Lalan. Banyuasin river has six branch rivers with river catchment area (RCA) of $\pm 1,114,700$ hectares; whereas Lalan river poses nine branch rivers with RCA of \pm 108.300 hectares (Badan Pusat Statistik, 2013). This assemblage, combined with high and low sea tides, made BAE becoming unique geographically. BAE as a shallow water bed with high sedimentation caused the formation of a developing island, named Ekortikus Island.

Sedimentation rate in BAE was $2.03 \mathrm{~cm}$ a year at $0-0,3 \mathrm{~m}$ under surface of estuary bed, an $8.9 \mathrm{~cm}$ a year at 2.1 $\mathrm{m}$ or at a range of $1.454 \mathrm{~kg} \mathrm{~m}-2$ day-1 (Purnomo, 2010). The average diameter size of sediment particle at BAE was d_50 $20.53 \mu \mathrm{m}-25.48 \mu \mathrm{m}$. Basic sediment characteristic was formed silt poorly sorted to moderately sorted and skewness dominant symmetrical (Affandi and Subakti, 2013). Sediment deposition research around the port of Tanjung Api-Api performed by Zulbahrum et al (2015) placing a potential barrier, results indicate that the rate of sediment deposition can be controlled and reduced to $2.35 \%-2.68 \%$. Handayani (2010) demonstrated that sedimentation has resulted in dramatic area-expa nsion of Ekortikus Island, about 22 fold within 21 years. In 1986, the area of Ekortikus Island was 14,640 hectares, in 1992 being 118,005 hectares, and in 2007 becoming 324,544 hectares. However, Ekortikus Island development becomes problematic to the function of estuary, especially those for the channeling of excess water from water cathment area of the rivers and those for sea 
transportation function. For these reasons; simulation should be developed to control island development; whether it needs to be stopped or at least to be slowed down.Simulation is an important tool to understand natural system in a specific region, such as an estuary as natural changes might occurs during a long or a very short period that is difficult to detect. Simulations has been used precisely to picture the development of Tsunami from the epicentrum (Gailler et al., 2013). Satelite data has revealed area expansion of Ekortikus Island, but they can not predict the future of the island.

Is the sedimentation in BAE can be controlled so that the island development can be slowed down or be stopped? The experiment was conducted through modeling and hydrodynamic simulation of BAE by FVM with triangle unstructured mesh.

\subsection{Sediment Deposition}

Estuary is a part of river system which role is to canal water runoff to the sea. Estuary waters are commonly used by human being as housing, fish catching and culture, transportation, harbor and industrial nice (Bangen, 2004). Sedimentation problems generally occur at locations where the sediment transporting capacity of the hydraulic system is reduced due to the decrease of the steady (currents) and oscillatory (waves) flow velocities and related turbulent motions (van Rijn, 2004). The sedimentation rate indices an existence of ecosystem imbalance in the hilly area such as reduction in land cover (Agus, 2004).

Sedimentation was affected by many factors, from upper water catchment area, river characteristics, and fusion between river flow and high-low tides. The fusion of river fresh water containing sediment particles with sea salt water create clumps of sediment particles, which are more easily sink in estuary. At low concentration, particles in the fluid are discrete and move easily; however, when become concentrated, particle movement is affected by other moving particles.

Sedimentation occurs when gravity power of the dissolved particles in the flowing liquid is greater than the hydrostatic power. Gravity power is related to size and particle special mass, from fine to big size particles. Fine particles will float before subside; even some dissolved materials, such as protein and pesticide, are difficult to subside (Anonymous, 2011). The relation effect of hydrostatic power and gravity power with the rate of particle sedimentation is formulated as follow (Zhiyao et al., 2008):

$$
\boldsymbol{v}_{\boldsymbol{s}}=\sqrt{\frac{2\left(\rho_{p}-\rho\right) g V_{p}}{\boldsymbol{C}_{\boldsymbol{D}} \boldsymbol{A}_{\boldsymbol{p}} \boldsymbol{\rho}}}
$$

Liu et al. (2012) employed emphirical equation to calculate settling velocity:

$$
v_{s}=\sqrt{\left(13.95 \frac{v}{d}\right)^{2}+1.09 s g d}-13.95 v / d
$$

where $\rho_{\mathrm{p}}=$ sediment particle density $\left(\mathrm{kg} \cdot \mathrm{m}^{-3}\right), \rho=$ water density $\left(\mathrm{kg} \cdot \mathrm{m}^{-3}\right), C_{D}=$ Drag Coefficient (non demension), $A_{p}=$ particle surface area, $V p=$ particle volume $\left(\mathrm{m}^{3}\right), \mathrm{g}=$ gravitation accelartion $\left(m \cdot \mathrm{s}^{-2}\right), v=$ viscocity coefficient, $d=$ average diameter of sediment particles $(m)$, and $s=\frac{\rho_{p}}{\rho}-1$;

\subsection{Modeling}

Modeling is a representative or abstraction of a real object, using some simplifications from complexity of a reality by showing direct and indirect relations and cause-effect reciprocal relations. An abstraction and simplification means that the complexity of an object is not presented anymore, but the important aspects of the reality do still present (Maria, 1997). The objective of modeling is to easily interpret, analyze the behavior a, manage, operate, and/or control a system so that we can obtain an expected result (Khadan, 2002).

Existing phenomena in an estuary are natural processes occurring in three dimensional space (3D) and time; hence, an estuary system is categorized as a highly complex system. To understand an estuary, we need some simplification without removing basic principles existing in its system, such as conservation law (Wilbert, 2009). This conservation law has been formulated in Navier-Stokes governing equation, as follow:

$$
\frac{\partial \rho \varphi}{\partial t}=-\nabla \cdot(\rho \varphi \vec{V})+\nabla \cdot(\mu \nabla \varphi)+S
$$

Equation (3) can be explained and simplified in a 2D system (Zulin, 2000) in a form of differential equation which portrait changes that occur in thermodynamic law, momentum and continuity. Where $\varphi$ is physical quantities, $\rho$ : density of fluid, $\vec{V}$ : velocity, $\mu$ : viscosity, $S$ : source term.

Governing equation in hydrodynamic system is a nonlinear equation with no exact solution, hence needs a 
numerical method. Numerical method is one of mathematical solution equation using arithmetic and some approaches, and used as an analytical method when using exact answer, solution is difficult or even impossible to achieve (Shalleh, 2008).

Important aspect in numerical solution is an achievement of discrete solution where dependent variable values are only obtained at certain points distributed in small elements as nodes. By knowing values of some points, the values of other points can be calculated through interpolation of local node values (Voller, 2009).

The essential aspect in numerical methods is the discretization of space and time. Spatial discretization in estuary study means geometrically dividing estuary into some volume/area units and to become small elements (finitesimals) which can be viewed as a discrete unity. Element shapes are rectangular, tetragonal or triangular. Discretization aims to ease equation solution in each element; therefore, the smaller the volume units the more accurate the solution although it increase recursion time (Olsen, 2000). Selection of an element shape is adjusted with the geometry of an estuary. Division of an estuary into smaller elements will form mesh or network. Rectangular elements will form structured mesh, whereas triangular elements will form unstructured mesh.

Time discretization in numerical method is dividing time by integrated span with some steps, $\Delta t=t_{n-1}-t_{n}$. In deciding time steps, $\Delta t$ was related to algorithm stability and numeric result accuracy. To control numeric algorithm stability, time steps should follow Courant-Friedrichs-condition (Sanders, 2008):

$$
\Delta t=\leq \frac{\Delta x}{u_{\max }}
$$

One numeric method is FVM, which is defined as a discreting technique that integrate volume element $(\Delta \Omega)$ in all domain. This technique was introduced in 1980 (Chandrashekhar, 2006). Roylance (2001) stated that FVM was accurate for studying fluid dynamics using computation as fluid phenomena are geometrically flexible.

Equation (3) is a governing equation to partially differential equation; so for FVM, the equation can be written in form of an integral equation (Begnudelli and Sanders, 2006) which consists of diffusion, advection, and source term.

$$
\frac{\partial}{\partial t} \int_{\Omega} U d \Omega+\oint_{\partial \Omega}(\boldsymbol{Q} \cdot \mathbf{n} d x+\boldsymbol{R} \cdot \mathbf{n} d y)=\int_{\Omega} S d \Omega
$$

where

$$
U=\left(\begin{array}{c}
h \\
u h \\
v h
\end{array}\right) ; \quad Q=\left(\begin{array}{c}
u h \\
u^{2} h+\frac{1}{2} g h^{2} \\
v h
\end{array}\right) ; \quad R=\left(\begin{array}{c}
v h \\
u v h \\
v^{2} h+\frac{1}{2} g h^{2}
\end{array}\right) S=\left(\begin{array}{c}
0 \\
g h \frac{\partial z_{b}}{\partial x}-C_{D} c u \sqrt{u^{2}+v^{2}} \\
g h \frac{\partial z_{b}}{\partial y}-C_{D} v \sqrt{u^{2}+v^{2}}
\end{array}\right)
$$

where $h$ : level water, $u . v$ : velocity in x- an y-directions, $C_{D}:$ drug coefficient

\subsection{Roe-Riemann Solver}

Roe-Riemann Solver is an approach based on Godunov scheme to calculate interface fluxes in two computationally close elements on space-time variables (Dullemond and Wang, 2009). By using Roe-Riemann-Solver, flux value at each face of elemental units can be approached to become 1D problem and be calculated by using Euler integration (Anastasiou, 1997).

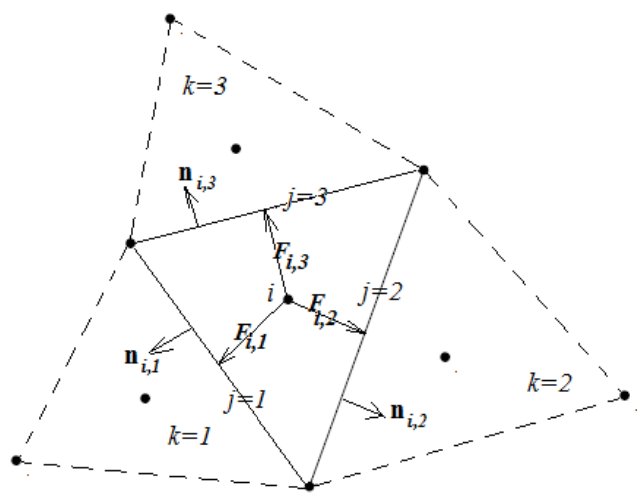

Figure 1. Fluxes entering through interface into neighbor triangle 
Total flux change in main triangle can be showed in following equation:

$$
\frac{\partial U_{i}}{\partial t}=-\oint_{\partial c} \boldsymbol{F} \cdot \boldsymbol{n} d S+S_{i} V_{\boldsymbol{i}}
$$

and

$$
\oint_{\partial c} \boldsymbol{F} . \mathbf{n} d S=\sum_{j=k(i)} F_{i, j} \Delta l_{j}
$$

To evaluate numerical $F_{i j}$ flux, fluxes at normal direction that entering border of neighboring triangle can be adopted locally, becoming 1D problem (Anastasiou, 1997). This can be calculated by using Jacobian transformation, resulting into following equation:

$$
\begin{gathered}
A=\frac{\partial(\boldsymbol{F} . \boldsymbol{n})}{\partial Q}=\left[\begin{array}{ccc}
0 & n_{x} & n_{y} \\
\left(c^{2}-u^{2}\right) n_{x}-u v n_{y} & 2 u n_{x}+v n_{y} & u n_{x} \\
\left(c^{2}-u^{2}\right) n_{y}-u v n_{x} & v n_{y} & 2 v n_{y}+u n_{x}
\end{array}\right] \\
\Lambda=\left(\begin{array}{l}
\lambda_{1} \\
\lambda_{2} \\
\lambda_{3}
\end{array}\right)=\left(\begin{array}{c}
u n_{x}+v n_{y} \\
u n_{x}+v n_{y}-c n \\
u n_{x}+v n_{y}+c n
\end{array}\right) R=\left(\begin{array}{ccc}
0 & 1 & 1 \\
n_{y} & u-c n_{x} / n & u+c n_{x} / n \\
n_{x} & v-c n_{y} / n & v+c n_{y} / n
\end{array}\right) \\
L=\left(\begin{array}{ccc}
-\left(u n_{y}+v n_{x}\right) / n & n_{y} / n^{2} & -n_{x} / n^{2} \\
\frac{u n_{x}+v n_{y}}{2 c n}+\frac{1}{2} & -n_{x} / c n & -n_{y} / c n \\
-\frac{u n_{x}+v n_{y}}{2 c n}+\frac{1}{2} & n_{x} / c n & n_{y} / c n
\end{array}\right)
\end{gathered}
$$

\section{Method}

An experiment was conducted to understand hydrodynamics of BAE, Banyuasin district, South Sumatra Province, especialy those related to transport of sedimentation and phenomenon on formation of Ekortikus Island. Research location was shown in Figure 2a, and restricted to the domain as shown in Figure 2b.

Hydrodynamic system of BAE is categorized as shallow water. When we neglect Coriolis force and wind shear stress, BAE model can use equation 5 , and the source term become:

$$
\left(\begin{array}{c}
0 \\
S_{x} \\
S_{y}
\end{array}\right)=\left(\begin{array}{c}
0 \\
-c_{D} u \sqrt{u^{2}+v^{2}} \\
-c_{D} v \sqrt{u^{2}+v^{2}}
\end{array}\right)
$$

Where $S x$ and $S y$ are energy losses as affected by friction of fluid flux in x direction and y direction with water bed. Therefore, $S x, y$ is determined by roughness of water bed, depth and flux speed (Benkhaldoun et al., 2006; Xin et al., 2012),

$$
S_{x}=n^{2} u \sqrt{u^{2}+v^{2}} / h^{4 / 3} \quad S_{y}=n^{2} v \frac{\sqrt{u^{2}+v^{2}}}{h^{\frac{4}{3}}} \quad n \text { : roughness coefficient }
$$




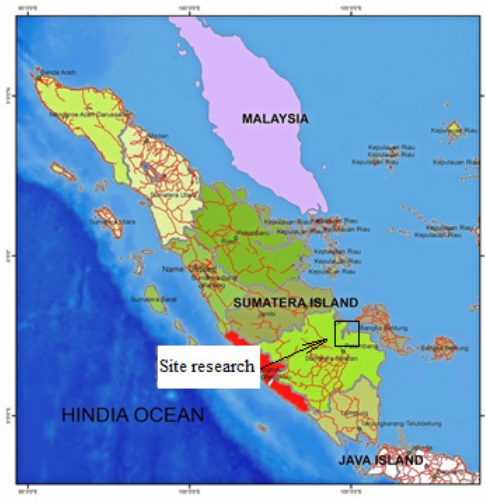

(a)

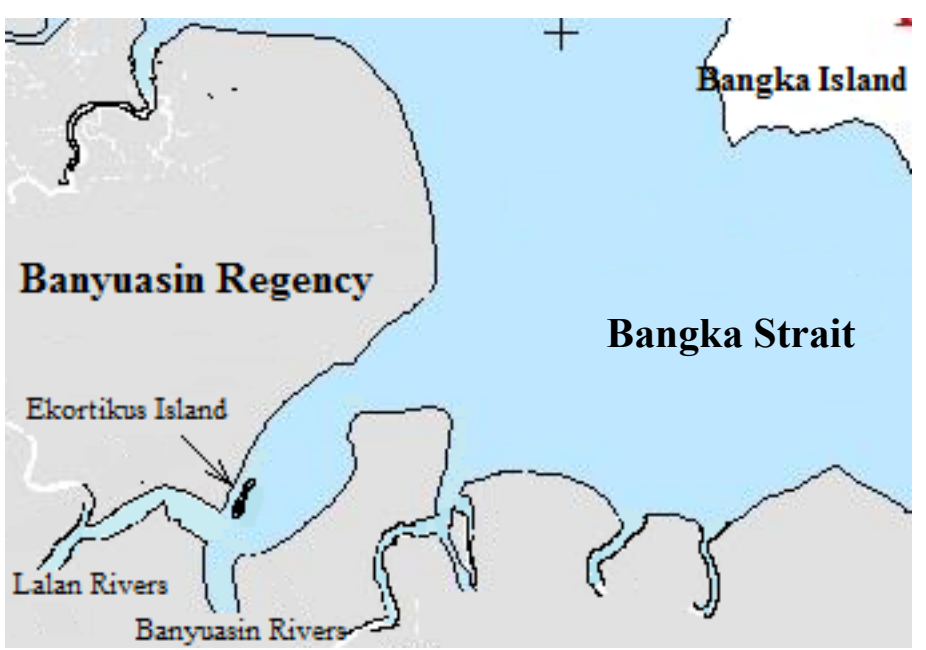

(b)

Figure 2. Research site in South Sumatra Province, Indonesia (a) with research domain of Banyuasin Estuary (b)

Equation 5, written in a discrete form:

$$
\boldsymbol{U}_{i}^{t+1}=\boldsymbol{U}_{i}^{t}+\frac{t^{n+1}-t^{n}}{V_{i}}\left\lceil-\sum_{k=1}^{3} \boldsymbol{F}_{i, j} \Delta l_{i j} p_{i, k}+S_{i}\right\rceil^{t+\frac{1}{2}}
$$

$\boldsymbol{F}_{i, j}$ flux traffic through interfaces was evaluated with Roe-Riemann approach, Eigen vector and Eigen value, whose details was discussed by Benkhaldoun et al. (2011).

Sediment deposition in an estuary bed will change estuary bed morphology. Morphological transformation of estuary bed can be calculated by using Exner equation (Simson and Sebastian, 2005):

$$
\begin{gathered}
(1-p) \frac{\partial z_{b}}{\partial t}+\frac{\partial q_{b}}{\partial x}+\frac{\partial q_{b}}{\partial y}=0 \\
\mathrm{q}_{\mathrm{b}}=\mathrm{Au}\left(\mathrm{u}^{2}+\mathrm{u}^{2}\right)
\end{gathered}
$$

$A$ : interaction constant (0-1); $p$ : sediment porosity; $q_{b}$ : sediment discharge; $\partial z_{b}$ : bed slope

Erosion $(E)$ in an estuary bed might be defined as a wearing away process of sediment due to the presence of turbulence flux. This is an antagonist process of sediment deposition $(D)$, which occurs as particles in water subside due to gravitaion power (Liu et al., 2012). In nature, these two processes can exist concurently in an area; hence, which one is dominant $(E>D$ or $E<D)$ will dictate whether bed load will deeper or shallower. Mathematically, this phenomenon can be presented as:

$$
\begin{aligned}
& D \simeq v_{s}\left(1-C_{a}\right) C_{a} \\
& E=\frac{\varphi\left(\theta-\theta_{c}\right) \sqrt{u^{2}+v^{2}}}{h d^{1 / 5}}, \quad \theta>\theta_{c} \\
& E=0, \quad \theta \leq \theta_{c}
\end{aligned}
$$

where $C_{a}$ : sediment concentration, $\theta$ : shear stress, $\theta_{c}$ : critical shear stress, $\varphi$ : erosion power coeficient, $h$ : depth (m), and $d$ : diameter of sediment-particel (m).

Simulation in this experiment aimed to quantify flux distribution with function of space and time, which was expressed with $\boldsymbol{U}_{i}^{t+1}$ in equation (8). $\boldsymbol{U}_{i}^{t+1}$ value was calculated by using a computer program that was developed with MATLAB software; numeric results were saved in spread sheet Excel form. Graphical data were drawn by using ArcGis software using a 3D Analyst Tools with Raster Interpolation type of Kriging.

Model validation needs field measurement of data and secondary relevant data. Field variables were measured, including (1) river border line, (2) flow speed, and (3) samples of estuary depth and bathymetry. The locations of sample for measurement are shown in Figure 3. 


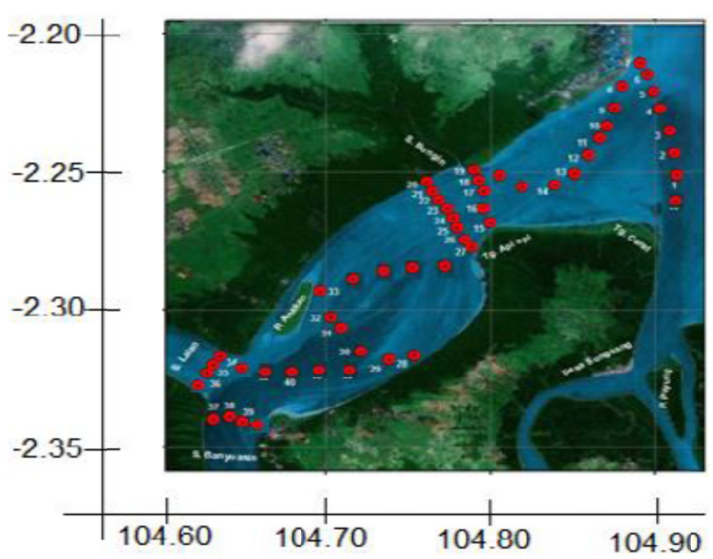

Figure 3. Sampling sites for measurement of field parameter

\section{Result and Discussion}

\subsection{Discretization}

Discretization of estuary body using pdetool MATLAB program modified and adapted to the research domain, resulted in three main parameters, i.e. node, index of triangle edges which are located in domain boundary, and triangle index. Discretization results of estuary body are shown in Figure 4. All three parameters were then broken down into discretization components which results were presented in Table 1.

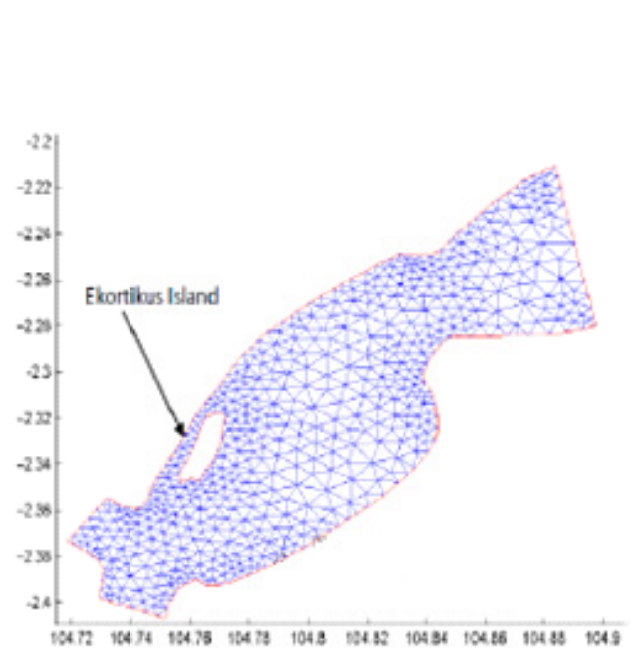

(a)

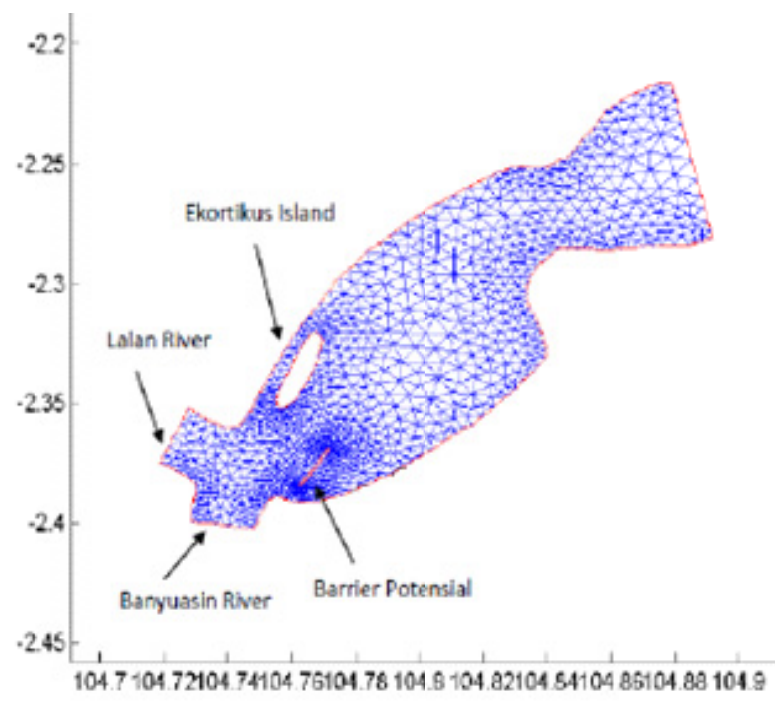

(b)

Figure 4. (a) domain discretization non Potential barrier; (b) the domain discretization with a potential barrier 
Table 1. Discretization parameters without and with treatment with putting the potential barrier at the mouth of the body

\begin{tabular}{lrr}
\hline Parameter & Without Potential & With Potential \\
\hline Total Node (node) & 964 & 1,268 \\
Number of Cells $\Delta$ (triangular) & 1,705 & 2,280 \\
The number of segments on the domain boundary (edge) & 233 & 258 \\
The minimum side length (m) & 70.44 & 51.04 \\
The maximum side length (m) & $1,030.15$ & $1,006.98$ \\
Wide minimum $\Delta(\mathrm{m} 2)$ & 70.45 & $1,460.17$ \\
Broad maximum $\Delta(\mathrm{m} 2)$ & $377,668.39$ & $379,398.55$ \\
$\Delta$ wide average $(\mathrm{m} 2)$ & $82,559.86$ & $61,668.6$ \\
Domain wide total $(\mathrm{m} 2)$ & $140,764,555.50$ & $140,604,555.50$ \\
\hline
\end{tabular}

\subsection{Morphology of Estuary Bed}

The interpolation of bathimetry data of BAE body demonstrated that the wing sides were shallower than those in the middle body (Figure 5). This data indicate that sedimentation rates were higher in the wing sides as compared to those in the middle body of BAE. These might be explained that in the wing sides a shear stress was greater than those in the middle of estuary body, and hence flux in the wing side become lesser and sediment deposition will occur easier.

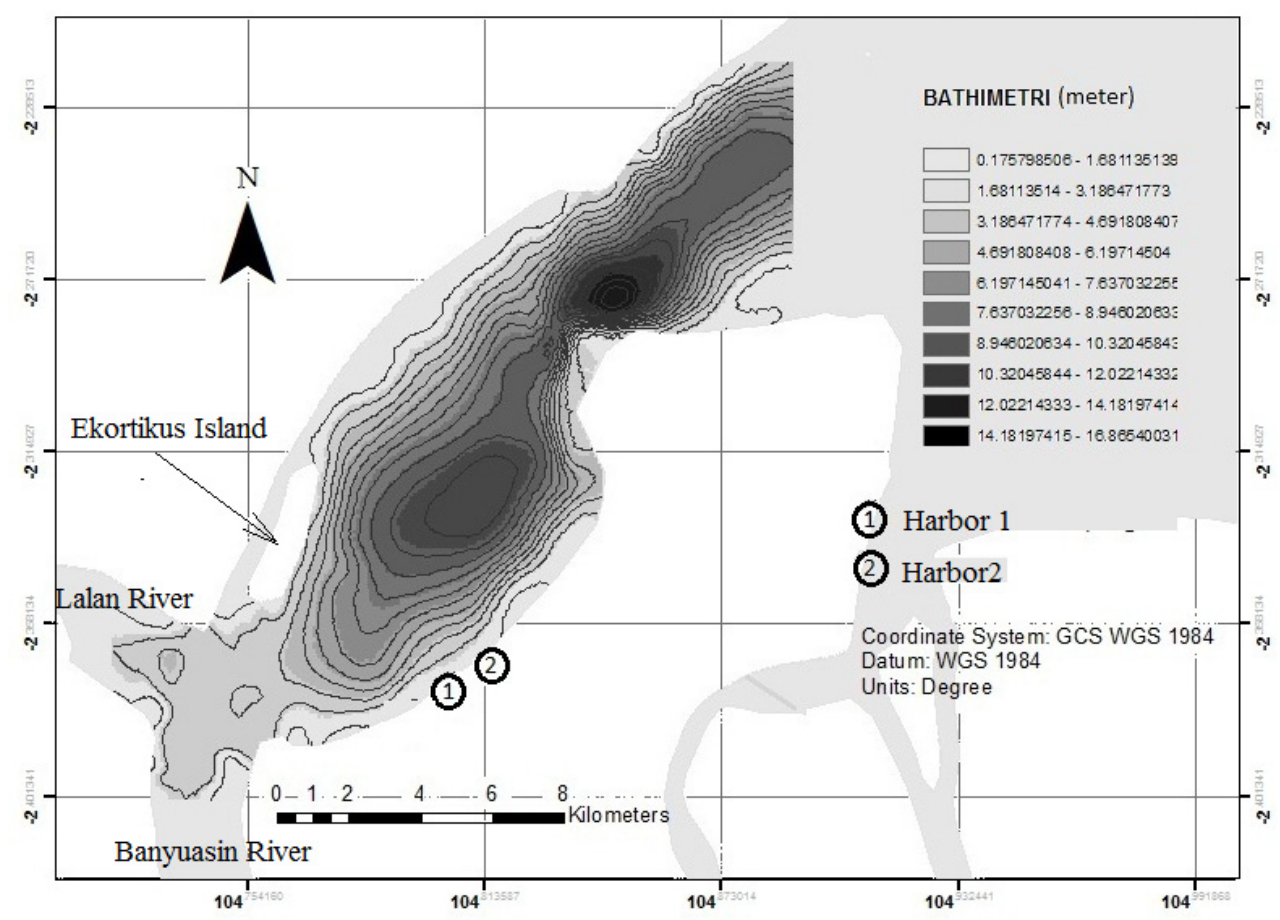

Figure 5. Estuary bed morphology of Banyuasin Estuary 


\subsection{Tidal Wave Pattern}

Tidal data in July 2010 around BAE was obtained from Sunsang station with a maximum height of $3.9 \mathrm{~m}$ and minimum $0.1 \mathrm{~m}$. The highest tide occurred on July 12, 2010 20:00 local time, and the lowest tide occurred at 10:00. Data were observed for 24 hours, starting at 10:00 (local time) on July 12, 2010 until 09:00 on July 13, 2010. The character of tidal generally demonstrate sinusoide functions. Figure 6 is an example of data tidal July 122010 , which will be used in the simulation in this study.

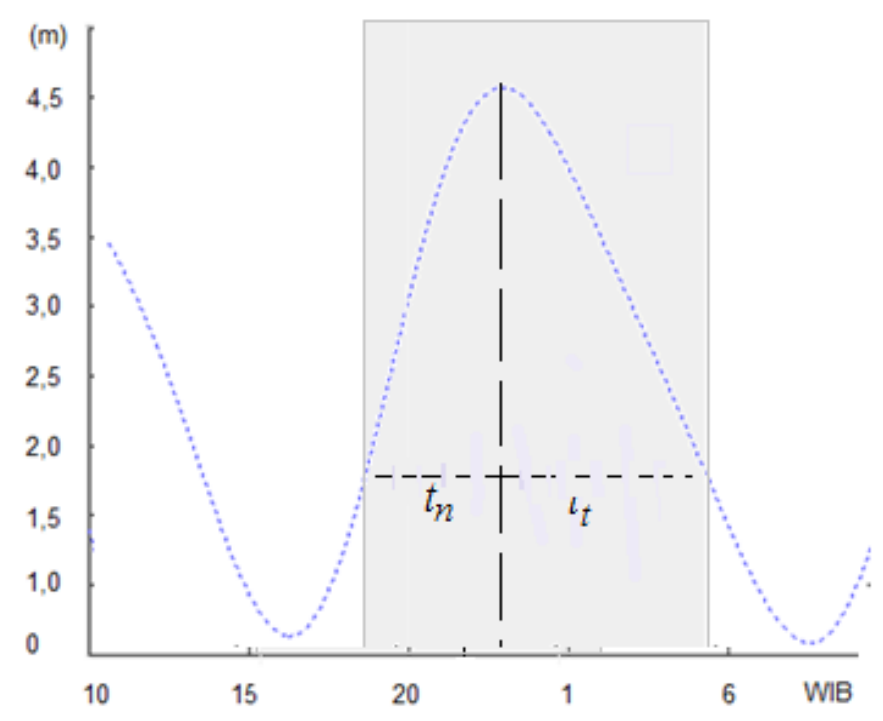

Figure 6. Daily Tidal Fluctuation at Banyuasin Estuary

\subsection{Dynamic Simulation}

Dynamic simulation is necessary to show the characteristics of the system within a certain time frame. Through dynamic simulation, it can be shown the distribution of flux and distribution of sediment deposition in the body of the estuary can change by time. Dynamic simulations performed on two conditions, namely the condition without treatment and with treatment simulation.

Simulation without treatment aims to determine the trend of sediment distribution pattern results are then compared to the current condition (existing condition). Current condition is the sediment deposition distribution shown by estuary body bathymetry patterns (Figure 6). From this figure, it can be shown sedimentation (sediment deposition) tends to occur at the edge of the estuary body, while at the center of the mouth of the body tends to be trough with a maximum depth $(\mathrm{h}<14 \mathrm{~m})$. Around the island Ekortikus, visible sedimentation occurs at the end of the Southwestern (SW), at the end of the Northeast (NE) and others occur on the right side of the island. Due to the dynamic nature condition of the estuary so that the bathymetry pattern may change at any time, in accordance with the conditions of flow dynamics are influenced by tide waves. But the island Ekortikus persists widening due to the accumulation of sediment deposition is ongoing continue.

Dynamic simulation with treatment is intended to understand the characteristics of the system when given treatment. Treatment in the system is to change the the flux direction and magnitude of Lalan river and Banyuasin river or put potential barrier in the form of rods with certain dimensions that are placed on certain coordinates in the body estuary. Provide treatment to the system is to change the direction of flux in turn control the distribution of sediment deposition.

Indeed control sediment deposition are things that can not be determined by exact, because the estuary is a dynamic system, has many variables that affect each other. Control does not mean eliminating or reducing the deposition of sediment in the estuary but the control is to obtain an optimal result that the distribution of sediment deposition will not cause problems with the function of the estuary. Reduce sedimentation is a step that must be done in the upstream area or in the watershed. Because the source of sediment derived is from erosion of the ecosystem processes upstream disruption.

Some assumptions are used in this simulation, one of it, that the flux of Lalan river and Banyuasin river flow at the constant speed, while the flux derived from tide waves is periodically in accordance with the tide waves 
period. Sediment particles is predominantly mud manifold particles mixed with sand (sand-mud) with a corrugated base surface shape (rippled), with sediment particle parameters listed in Table 4.

\subsubsection{Dynamic Simulation without Treatment}

Simulation without treatment aims to determine the characteristics of the system, especially the tendency of the sediment deposition distribution within 9 hours of simulation time (at 15 till 24). Simulation flux of the river Lalan $\boldsymbol{U}_{1}$ and Banyuasin river $\boldsymbol{U}_{2}$ then interact with the flux of tide waves $\boldsymbol{U}_{3}$. Tide waves flux is a sinusoidal function (equation 12). The first value of three fluxes were given based on the average field conditions, each value of flux is:

$$
\begin{array}{ccc}
\boldsymbol{U}_{1}=f\left(h_{1}=3 \mathrm{~m},\right. & u_{1}=0.4 \mathrm{~m} / \mathrm{s}, & \left.v_{1}=0.001 \mathrm{~m} / \mathrm{s}\right) ; \\
\boldsymbol{U}_{2}=f\left(h_{2}=3 \mathrm{~m},\right. & u_{2}=0.001 \mathrm{~m} / \mathrm{s}, & \left.v_{2}=0.3 \mathrm{~m} / \mathrm{s}\right) ; \\
\boldsymbol{U}_{3}=f\left(h_{3}=f(C, t) m, u_{3}=-0.2 \mathrm{~m} / \mathrm{s},\right. & v_{3}=0.001 \mathrm{~m} / \mathrm{s} ;
\end{array}
$$

Figure $7 \mathrm{a}$ is a dynamic simulation results without treatment, showing the distribution of sediment deposition illustrated with black-and-white raster and flux direction is indicated by the arrow. This image shows the initial condition (minute 20th) in which the flux from river Lalan $\boldsymbol{U}_{1}$ and river Banyuasin $\boldsymbol{U}_{2}$ and flux of tide waves $\boldsymbol{U}_{3}$ are starting to get into the BAE. The sediment deposition direction follows the flux of the rivers and also the flux of the tides waves, distributed in such a way in which darker colors show relatively large sediment deposition rate. Material sediment that carried by the river flow was depositioned in southwest of the island, at this stage, the rate of deposition is larger (darker colors), based on a large-scale deposition of sediment is sediment around $0.00321-0.00322 \mathrm{~m} / \mathrm{s}$ Meanwhile the sediment deposition was derived from the tide wave shove into the estuary body distributed to the edge of the estuary, this thing because the speed of the flow slowed in the edge section.

Figure $7 \mathrm{~b}$, is the condition of the sediment deposition distribution in the 80th minute, ierwhere rivers flow flux and tides flow flux met, it is shown the existence of vortex flow (turbulence). In this condition, sediment deposition is dynamically increased. Sediment carried by stream was widely distributed and moves to the right edge of the island. It is also common in the change of sediment distribution by tidal wave, sediment distribution tends to move toward the edge of the estuary body. Meeting of fluxs of rivers and tidal wave flux caused turbulence, which in that area tends to cause erosion and sediment deposition decreases. In the picture also shows a high rate of sediment deposition in the Northeast end of the Ekortikus island, this led to the widening of Ekortikus island area into that direction. In the 80th minute, there is increased sediment deposition rate to the maximum number $0.003259 \mathrm{~m} / \mathrm{s}$

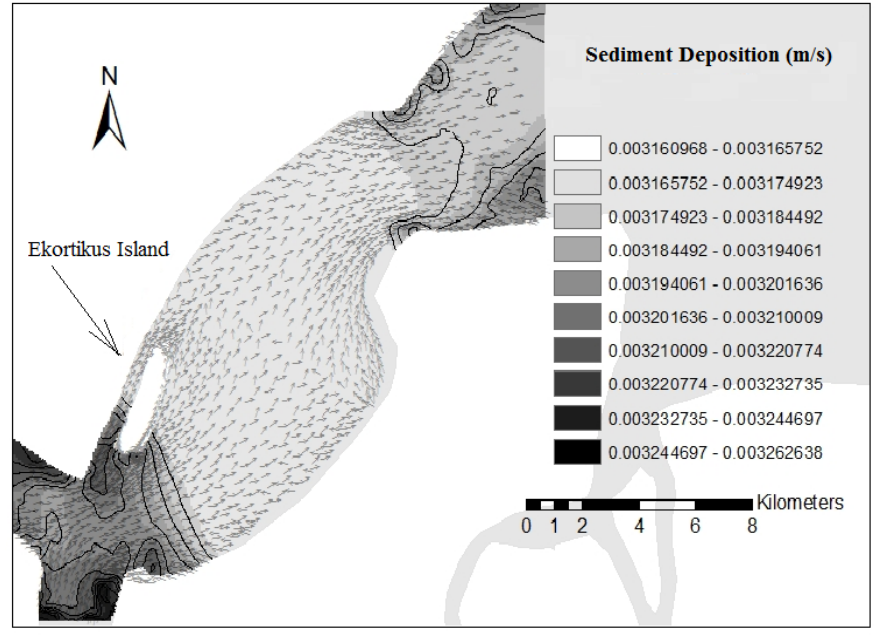

(a) 


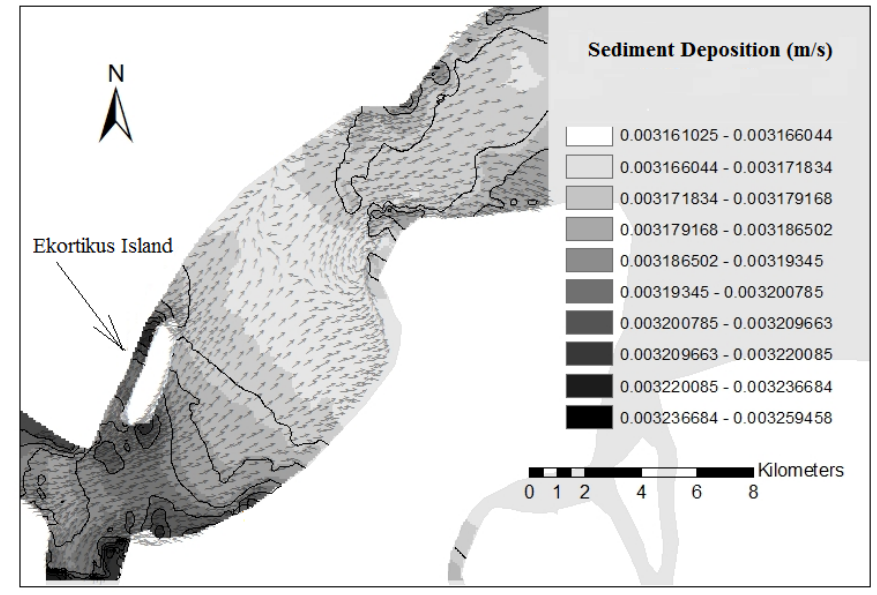

(b)

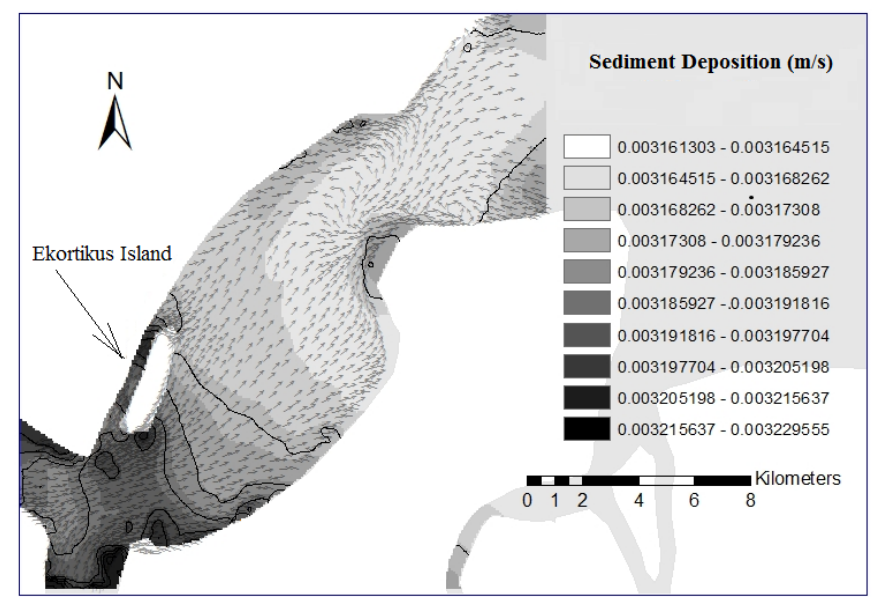

(c)

Figure 7. Distribution of sediment deposition without treatment

Figure $7 \mathrm{c}$ shows the distribution velocity and sediment deposition conditions where as the flux of the tidal wave is going down. Dominant direction of flux towards the exit of the estuary, this causes sediment deposition on the BAE tend towards stable with sediment deposition distribution is divided into 4 levels, the highest is in the region of the edge of the estuary body. It is because the flow velocity in this region is relatively slower.

When the tide wave is going down to lowest level, the transport of sediment material moving towards the sea, the flux rate increases so that the rate of sediment deposition in the BAE is low although some sedimentary material has been settled. When the flow velocity reaches the maximum value, the process of erosion is more dominant than the deposition process. Figure $7 \mathrm{c}$ shows the white color is more dominant in the middle of the estuary body, in that area, the flux rate is great and turbulence occur, causes erosion at the base of the estuary.

\subsubsection{Dynamic Simulation with Changing Magnitude of River Flux}

Simulation with treatment by changing the flux of Lalan river $\boldsymbol{U}_{1}$ and Banyuasin river $\boldsymbol{U}_{2}$. Under normal condition, $\boldsymbol{U}_{1}>\boldsymbol{U}_{2}$, this is due to the watershed of the Lalan river is broader than Banyuasin river, Lalan river elevation also $\geq 3 \%$, is higher than Banyuasin river.

Simulated by changing magnitude of the flux Lalan river and Banyuasin river will be $\boldsymbol{U}_{1}<\boldsymbol{U}_{2}$, flux respectively:

$$
\begin{array}{ccc}
\boldsymbol{U}_{1}=f(=3 \mathrm{~m}, & u_{1}=0.2 \mathrm{~m} / \mathrm{s}, & \left.v_{1}=0.001 \mathrm{~m} / \mathrm{s}\right) ; \\
\boldsymbol{U}_{2}=f(=3 \mathrm{~m}, & u_{2}=0.001 \mathrm{~m} / \mathrm{s}, & \left.v_{2}=0.4 \mathrm{~m} / \mathrm{s}\right) ; \\
\boldsymbol{U}_{3}=f\left(=f(C, t) m, u_{3}=-0.2 \mathrm{~m} / \mathrm{s},\right. & v_{3}=0.001 \mathrm{~m} / \mathrm{s} ; \quad \text { and } \\
\boldsymbol{U}_{1}<\boldsymbol{U}_{2} &
\end{array}
$$


Figure 8a shows the distribution of flow sediment deposition, in the beginning of the simulation (20th minute) can be seen in the middle of the estuary body is random (turbulent). The situation is different when compared with no treatment system (Figure 7). Shown is also the movement of the sediment deposition distribution in the form of contour lines tend to be flat against the direction of flux. This means that sediment deposition is more evenly distributed in the estuary body. Compare to also after 80 minutes, as shown in Figure $8 \mathrm{~b}$. sediment deposition on the Southwestern of the Ekortikus island, sediment deposition is not massive but distributed more evenly and thinner (lighter color), if compare Figure $7 \mathrm{~b}$ to Figure 8b, at which point the system is not treated.

When the tidal wave began to recede (Figure $8 \mathrm{~b}$ ), then the direction of Tidal Wave flux to change direction towards the estuary body out. When the rivers flux and flux of Tidal Wave reinforce each other so that the deposition process has begun to decrease, dominated by the process of erosion, it is shown relative contour color brighter, but the distribution of sediment deposition still occurs at particular spots and groups (Figure 8c).

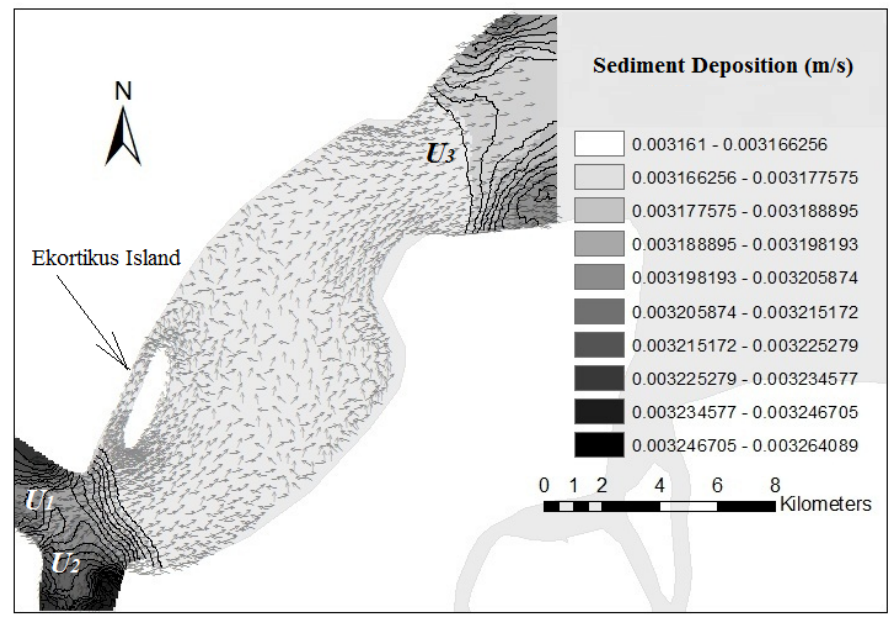

(a)

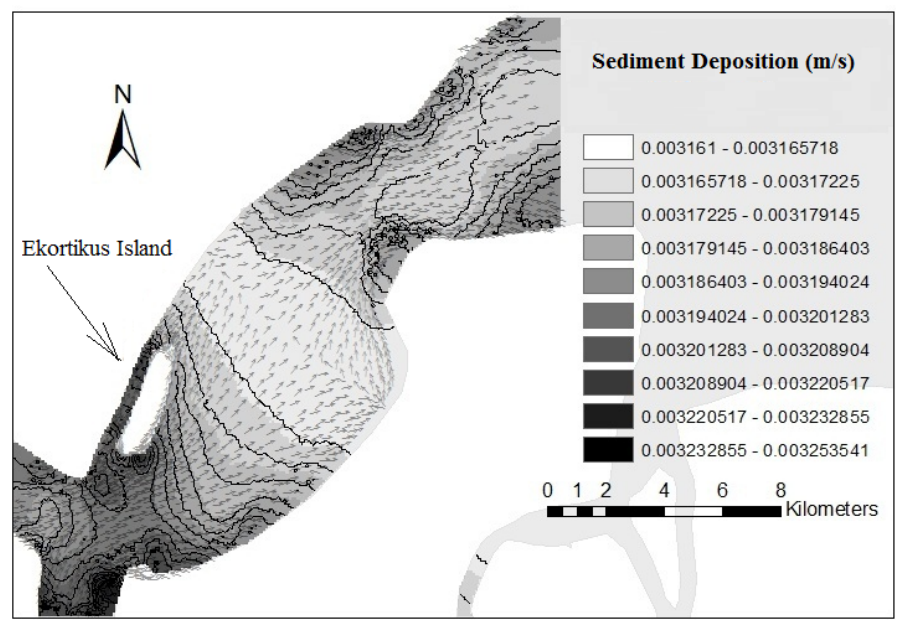

(b) 


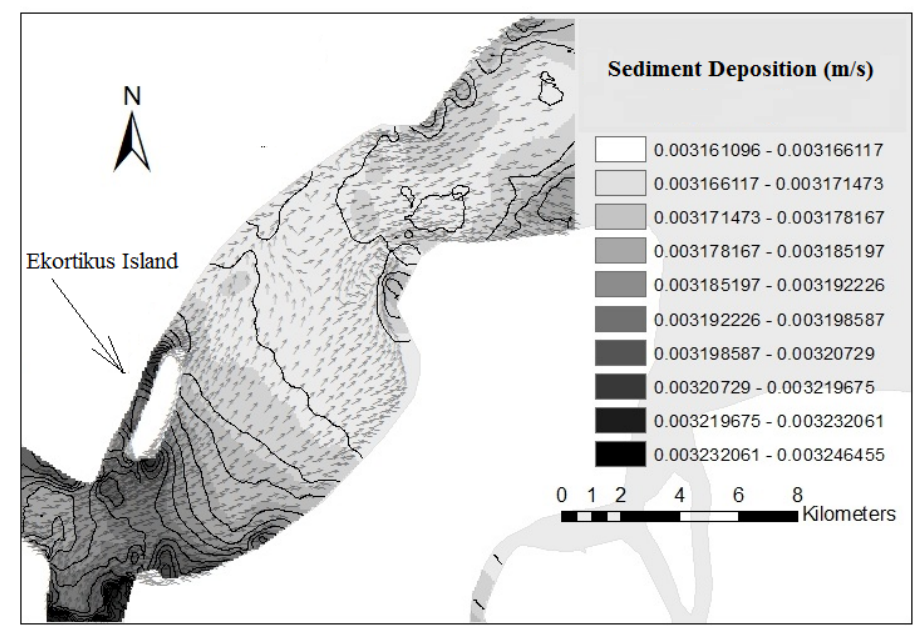

(c)

Figure 8. Distribution of sediment deposition with $\boldsymbol{U}_{1}<\boldsymbol{U}_{2}$

\subsubsection{Dynamic Simulation with a Potential Barrier Treatment}

Simulated by placing a potential barrier at the estuary body at the coordinates xo $=104767$, yo $=2,377$; Length $=2000 \mathrm{~m}$; Width $=80 \mathrm{~m}$; angle of inclination to the axis of abscissa $\alpha=60^{\circ}$. Fluxes of each:

$$
\begin{array}{ccc}
\boldsymbol{U}_{1}=f(=3 \mathrm{~m}, & =0.4 \mathrm{~m} / \mathrm{s}, & =0.001 \mathrm{~m} / \mathrm{s}) ; \\
\boldsymbol{U}_{2}=f(=3 \mathrm{~m}, & =0.001 \mathrm{~m} / \mathrm{s}, & =0.3 \mathrm{~m} / \mathrm{s}) ; \\
\boldsymbol{U}_{3}=f(=f(C, t) m,=-0.2 \mathrm{~m} / \mathrm{s}, & =0.001 \mathrm{~m} / \mathrm{s} ;
\end{array}
$$

Early simulations at minute 20, shown in Figure 9a, that the presence of a potential barrier at the estuary body causing turbulence, especially at the end of the rod. Meanwhile on the rod side, the declination of flow rate, thus in this section becomes high sediment deposition, this appears on the color raster image darker. Flux from the tide waves enters the estuary body, and the raster on estuary mouth is relatively dark, indicating that sediment deposition rate is relatively large.

In the 40th minute, shown in Figure 9b, that sediment deposition tends uniformly to the entire estuary body and no visible presence on the island Ekortikus deposition, except at the end of the potential barrier. This condition is relatively stable until the 120th minute (Figure 9b), and the deposition rate tends to decrease as seen on relative raster color becomes brighter. Deposition rate happens on certain spots, as seen in the contour lines are closed.

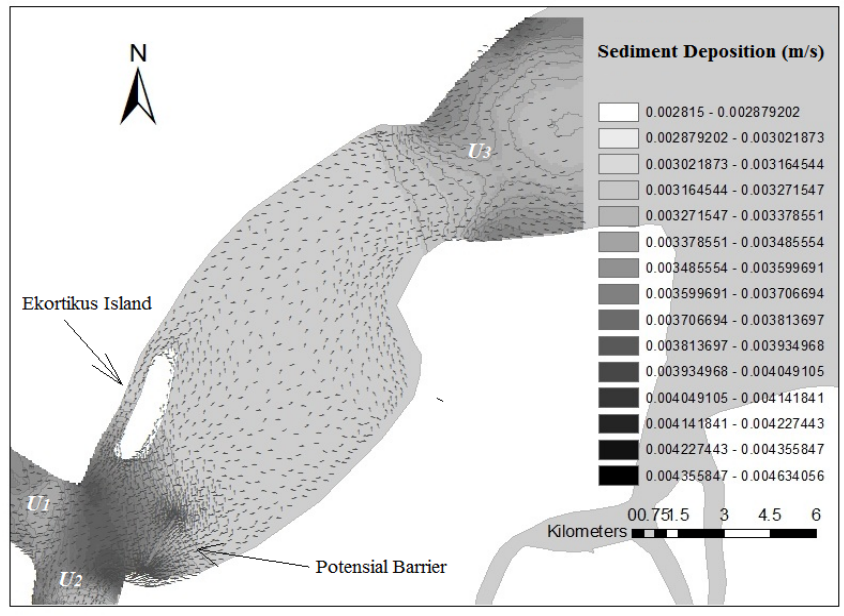

(a) 


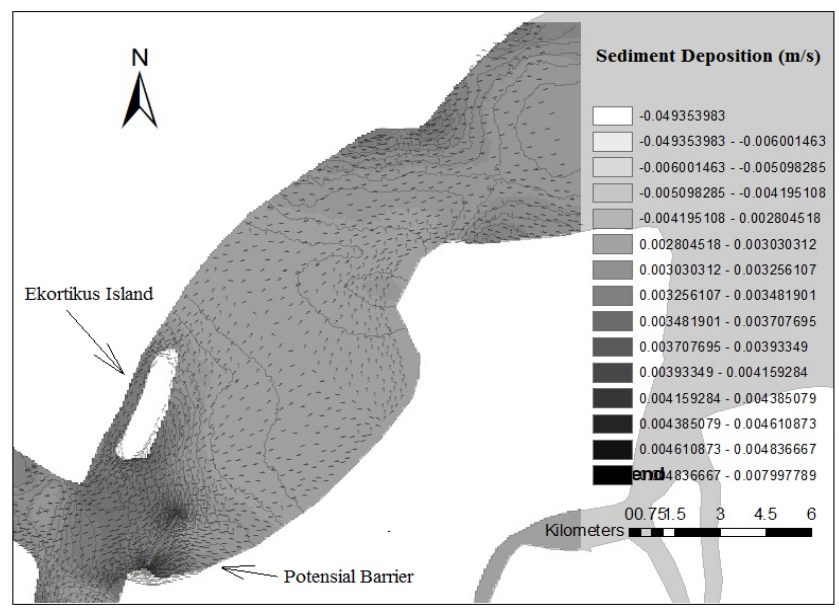

(b)

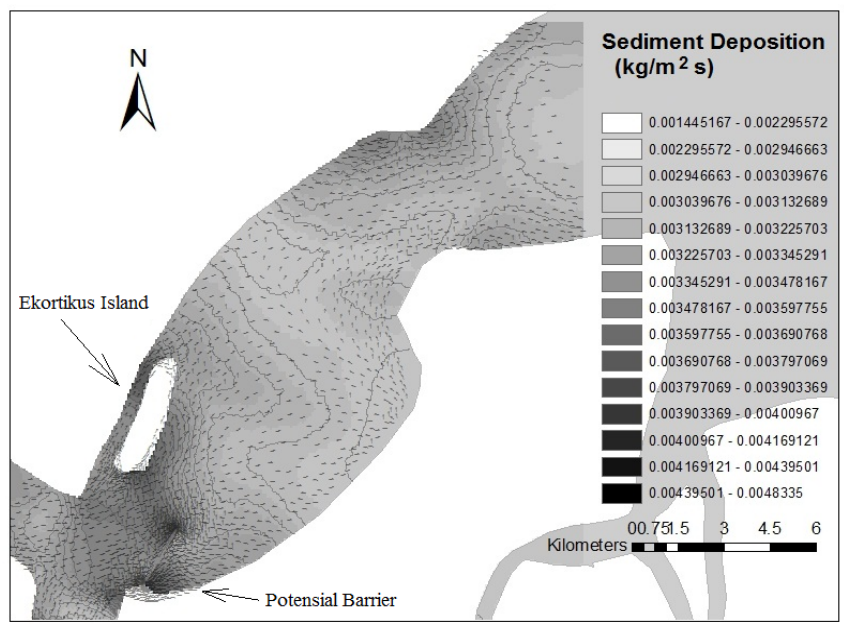

(c)

Figure 9. Sediment deposition distribution with a potential barrier treatment

\section{Conclusion}

1) Changes of basic morphological estuary is dynamic, it is indicated the change in the deposition distribution of any change in simulation time.

2) Ekortikus island formation, was due to the high rate of sediment deposition that accumulated in a long time. Also influence of the flow pattern caused by the confluence of two flow fluxes of Lalan river and Banyuasin river. Flux of the river Lalan $\boldsymbol{U}_{\boldsymbol{1}}$ is greater than the flow flux Banyuasin $\mathrm{U}_{2}$, causing the dead flow (dead water) at the part where Ekortikus island formed. This is supported by the results of the simulation through engineering to convert speed into $\boldsymbol{U}_{2}>\boldsymbol{U}_{1}$, sediment deposition does not affect to the accreation of Ekortikus island expressly extensive than when $\boldsymbol{U}_{1}>\boldsymbol{U}_{2}$.

3) The accreation of Ekortikus island at the end of Southwestern caused by deposition of sediment originating from flux transport of Lalan river and Banyuasin river. While the sediment deposition occurred in the Northeast end of the island Ekortikus derived from transport flux tides waves.

4) Simulation with systems engineering, through the potential barrier placement results can be shown that around the potential barrier occurs a higher sediment deposition (especially at the end of the barrier) than on the other side. This is indicated by the color raster darker in the end of the barrier and brighter on the other side. Also can be shown that the deposition around the island Ekortikus is not explicitly visible rather than without system engineering. It is concluded that the potential placement of a barrier can control the deposition of sediments in order to avoid the widening of Ekortikus island. 


\section{Discussion}

1) To obtain more accurate results can be done by reducing the volume of a triangular discrete or increase the number of triangular elements of the study domain. The risk is that it will add simulation time due to the increase of iteration numbers.

2) Sediment optimization control with a potential placement of barrier is determined by the dimensions and the coordinates of placement.

3) Control of sediment deposition can be done in the BAE, while reducing the deposition rate is determined in the river upstream to maintain the balance of the ecosystem in order to avoid erosion rates.

\section{References}

Affandi, A. K., \& Surbakti, H. (2012). Distribusi Sedimen Dasar di Perairan Pesisir Banyuasin. Sumatera Selatan, Maspari Journal, 4, 33-39.

Agus, F. N. M. (2004). Dampak Hidrologis Hutan, Agroforestri, dan Pertanian Lahan Kering sebagai Dasar Pemberian Imbalan kepada Penghasil Jasa Lingkungan di Indonesia. Prosiding Lokakarya di Padang/Singkarak, Sumatera Barat, Indonesia, 25-28 Pebruari 2004. ICRAF-SEA, Bogor, Indonesia.

Anastasiou, K., \& Chan, C. T. (1997). Solution of the 2D Shallow Water Equations Using the Using the Finite Volume Method on Unstructured Triangular Meshes. Journal Numerical Methods in Fluids, 24, 1225-1245. http://dx.doi.org/10.1002/(SICI)1097-0363(19970615)24:11<1225::AID-FLD540>3.0.CO;2-D

Anonim. (2011). Stream_power. Retrieved August 20, 2011, from http://en.wikipedia.org

Bangen, D. G. (2004). Menuju Pembangunan Pesisir dan Lautan Berkelanjutan Berbasis ekosistem. P4L. Bogor. Indonesia.

Begnudelli, L., \& Sanders, F. B. (2006). Unstructured Grid Finite-Volume Algorithm. Journal of Hydraulic Engineering, 132(4), 371. http://dx.doi.org/10.1061/(ASCE)0733-9429(2006)132:4(371)

Benkhaldoun, F. I., Elmahi, S. S., \& Said, M. (2011). A two-dimensional Finite Volume Solution of Dambreak Hydraulics over Erodible Sediment Beds. In Finite volumes for complex applications. VI. Problems \& perspectives. Volume 4 of Springer Proc. Math., pages 875-891. Springer, Heidelberg.

BPS. (2013). Banyuasin dalam Angka, Kabupaten Banyuasin.

Chandrashekhar, V. (2006). Control Volume Finite Element Method for the 2-Dimensional Convection-Difufusion Equation. Department of Mechanical Engineering Purdue University, India.

Dullemond, C. P., \& Wang, H. H. (2009). Retrieved April 22, 2013, from http://www.ta.uni-heidelberg.de/ dullemond/lectures/num_fluid_2009/index.shtml

Gailler, A., Hébert, H., Loevenbruck, A., \& Hernandez, B. (2013). Simulation systems for tsunami wave propagation forecasting within he French tsunami warning center. Nat. Hazards Earth Syst. Sci., 13, 2465-2482. http://dx.doi.org/10.5194/nhess-13-2465-2013

Handayani, Y. (2010). Pemantauan Perubahan Lingkungan Perairan Berdasarkan Tingkat Sedimentasi Menggunakan Analisis Data Citra Satelit Landsat di Wilayah Pesisir Timur Banyuasin Kabupaten Banyuasin Sumatera Selatan, Pusat Data Rawa. Palembang. Indonesia.

Hartoni dan Agussalim, A. (2007). Laju sedimen tersuspensi di wilayah Pembangunan Pelabuhan Tanjung Api-api Muara Sungai Banyuasin Kabupaten Banyuasin. Jurnal Penelitian Sain, 10(2), 204-211.

Khadan, N. (2002). Modeling Tools for Environmental Engineers and Scientists. CRC Press. New York.

Maria, A. (1997). Introduction to Modeling and Simulation. Proceedings of the 1997 Winter Simulation Conference, State University of New York at Binghamton. http://dx.doi.org/10.1145/268437.268440

Olsen, N. R. B. (2000). CFD Algorithms for Hydraulic Engineering. Departement of Hydraulic Environmental Engineering the Norwegian Univ. Of Science and Technology.

Pangestu, H., \& Helmi, H. (2013, December). Analisis Angkutan Sedimen Total pada Sungai Dawas Kabupaten Musi Banyuasin. Jurnal Teknik Sipil dan Lingkungan, 1(1).

PP Nomor 51 Tahun. (2014). Tentang Kawasan Ekonomi Khusus Tanjung Api-Api.

Pritchard, D. W. (1967). What is an estuary: physical viewpoint. In G. H. Lauf (Ed.), Estuaries (pp. 3-5). A.A.A.S. Publ. 83. Washington, DC. 
Purnomo, R. (2010, June). The Rate of Sedimentation Estimation of Tanjung Api-api Estuary South Sumatera by Using ${ }^{210} \mathrm{~Pb}$ Profile. Bulletin of The Marine Geology, 25(1).

Sanders, B. F. (2008). Integration of a Shallow Water Model with a Local Time Step. Journal of Hydraulic Research, 46(4), 466-475. http://dx.doi.org/10.3826/jhr.2008.3243

Shalleh, S. (2008). Computer for Numerical Methods Using Visual C++. John Wiley \& Sons, Inc., Hoboken, New Jersey.

Simpson, G., \& Sebastian, C. (2005). Coupled model of surface water flow, sediment transport and Morphological Evolution. Journal Computers \& Geosciences, 32, 1600-1614. http://dx.doi.org/10.1016/j.cageo.2006.02.020

VanRijn, L. C. (2004). Estuarine and Coastal Sedimentation Problems. Proceedings of the Ninth International Symposium on River Sedimentation October 18 - 21, 2004, Yichang, China.

Voller, V. R. (2008). Basic Control Volume Finite Element Methods for Fluids and Solid. World Scientific Publishing Co. Pte. Ltd, Singapore.

Zhiyao, S., Tingting, W., Fumin, X., \& Ruijie, L. (2008). A Simple Formula for Predicting Settling Velocity of Sediment Particles. Journal Water Science and Engineering, 1(1), 37-43. http://dx.doi.org/10.1016/S1674-2370(15)30017-X

Zhou, J. G., Causon, D. M., Ingram, D. M., \& Mingham, C. G. (2002). Numerical Solutions of the Shallow Water Equations with Discontinuous Bed Topography. Int. Journal. Numer. Meth. Fluids, 38, 769-788. http://dx.doi.org/10.1002/fld.243

Zulbahrum, C., Eddy, I.., Rasyid, M. R., Ngudiantoro, \& Siti, M. B. (2015). Reducing Deposition Rate of Sediment in Tanjung Api-Api Harbor, Modeling Using Finite Volume Method with Triangular Unstructured Mesh. AARJMD, 1(32), 90-107.

Zulin, H., Huimin, H., \& Kejian, C. (2000). Numerical Simulation of Flow and Concentration Field in Tidal Areas Using Triangular Grids. College of Water Resources \& Environment, Hohai University, Nanjing. Retrieved November 22, 2011, from http://www.paper.edu.cn/.../wanghuimin

\section{Copyrights}

Copyright for this article is retained by the author(s), with first publication rights granted to the journal.

This is an open-access article distributed under the terms and conditions of the Creative Commons Attribution license (http://creativecommons.org/licenses/by/3.0/). 